\title{
Physicochemical properties and toxicities of hydrophobic piperidinium and pyrrolidinium ionic liquids
}

\author{
Justin Salminen ${ }^{1,3}$, Nicolas Papaiconomou ${ }^{1,2}$, R. Anand Kumar ${ }^{1}$, Jong-Min Lee ${ }^{1,2}$, \\ John Kerr ${ }^{3}$, John Newman ${ }^{1,3}$ and John M. Prausnitz ${ }^{1,2}$ \\ ${ }^{1}$ Department of Chemical Engineering, University of California, Berkeley, \\ CA 94720-1462, USA. \\ ${ }^{2}$ Chemical Sciences Division, Lawrence Berkeley National Laboratory, Berkeley, \\ CA 94720, USA. \\ ${ }^{3}$ Environmental Energy Technology Division, Lawrence Berkeley National Laboratory, \\ Berkeley, CA 94720, USA.
}

Some properties are reported for hydrophobic ionic liquids (IL) containing 1-methyl-1-propyl pyrrolidinium [MPPyrro] $]^{+}$1-methyl-1-butyl pyrrolidinium [MBPyrro] ${ }^{+}$, 1-methyl-1-propyl piperidinium [MPPip $]^{+}, \quad$ 1-methyl-1-butyl piperidinium [MBPip $]^{+}, \quad$ 1-methyl-1octylpyrrolidinium [MOPyrro] $]^{+}$and 1-methyl-1-octylpiperidinium [MOPip] ${ }^{+}$cations. These liquids provide new alternatives to pyridinium and imidazolium ILs. High thermal stability of an ionic liquid increases safety in applications like rechargeable lithium-ion batteries and other electrochemical devices. Thermal properties, ionic conductivities, viscosities, and mutual solubilities with water are reported. In addition, toxicities of selected ionic liquids have been measured using a human cancer cell-line. The ILs studied here are sparingly soluble in water but hygroscopic. We show some structure-property relationships that may help to design green solvents for specific applications. While ionic liquids are claimed to be environmentally-benign solvents, as yet few data have been published to support these claims.

Keywords: Ionic liquids, hydrophobic, piperidinium, pyrrolidinium, properties, safety, toxicity 


\section{Introduction}

Ionic liquids (ILs) provide a class of solvents composed only of ions. Typical ionic liquids contain large organic cations, such as ammonium, imidazolium, pyridinium, piperidinium or pyrrolidinium cations, and halogen, fluorinated or organic anions. ${ }^{1-16}$ Ionic liquids are often referred to as environment-friendly and safe solvents because, at normal temperatures, they have essentially zero vapor pressure, and because they have high thermal stability. Ionic liquids exhibit a broad range of physico-chemical properties, depending on the anion and cation. Many studies have investigated thermal stability, melting points, densities, viscosities, mutual solubilities with water and conductivities. ${ }^{1-16}$ However, very few toxicological studies have been reported for ionic liquids. There is growing interest in cytotoxicities, in aqueous environmental impact as well as in structure -

activity relationship for ILs. ${ }^{17-28}$ Only few reports have used human cancer cells. ${ }^{18,22,26}$ For extraction of organic solutes or offensive metallic cations from water, we require highly hydrophobic ionic liquids that have very low solubility in water. Water-immiscible ionic liquids used previously for metal-ion extraction from water exhibit solubilities in water that are too large for industrial extraction processes. ${ }^{29-33}$ Previous work described the synthesis of new hydrophobic imidazolium and pyridinium ionic liquids that show low solubilities in water. ${ }^{15,16}$

In this work, we report some physico-chemical properties and toxicities of ionic liquids containing 1-methyl-1-propyl pyrrolidinium [MPPyrro] ${ }^{+}$, 1-methyl-1-butyl pyrrolidinium [MBPyrro] $]^{+}$, 1-methyl-1-propyl piperidinium [MPPip] $]^{+}$, 1-methyl-1-butyl piperidinium [MBPip $^{+}$, 1-methyl-1-octylpyrrolidinium [MOPyrro $]^{+}$and 1-methyl-1-octylpiperidinium $[\mathrm{MOPip}]^{+}$cations with selected anions. We discuss here the influence of cation or anion on the melting point, thermal stability, solubility in water, water content, viscosity, conductivity and cytotoxicity. Figure 1 shows ionic liquid structures and abbreviations for ILs studied here.

\section{Synthesis}

Synthesis methods are the same as those reported in previous work. ${ }^{15,16}$ Piperidinium or pyrrolidinium bromide was synthesized first. Then, a two-step metathesis procedure was carried out. Purity was checked by NMR and elemental analysis. Halide impurities were 
checked by a silver-nitrate test.

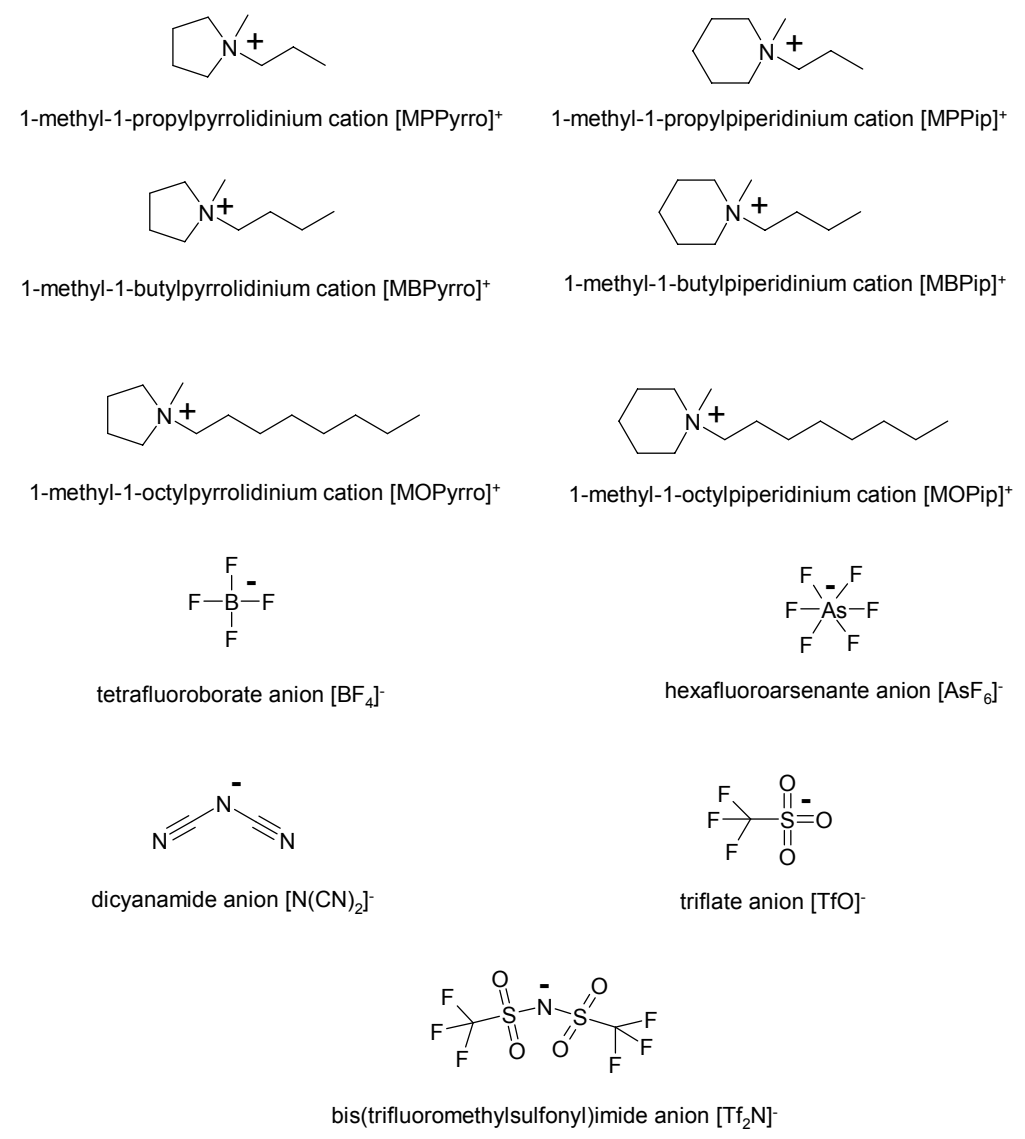

Figure 1. Structures and abbreviations for some pyrrolidinium and piperidinium ionic cations and selected anions.

\section{Phase properties and thermal stability}

Ionic liquids decompose at $200-340^{\circ} \mathrm{C}$ depending on the type of cation and anion. High thermal stability of an ionic liquid increases safety in applications like rechargeable lithium-ion batteries and other electrochemical devices. In some of these electrochemical applications, ionic liquids are considered as electrolytes mixed with polymers and lithium salts. ILs have a clear advantage because they are non-volatile, conductive, and decomposition products tend to be non-flammable.

Table 1 shows some thermal properties of piperidinium and pyrrolidinium ionic liquids.

Melting points and glass-transition temperatures were measured by differential scanning calorimetry (Perkin Elmer DSC 7). Ionic liquids were dried in a drying pistol at 1 mbar and $60{ }^{\circ} \mathrm{C}$ or in a vacuum oven and in an antechamber for at least 48 hours in the presence of 
$\mathrm{P}_{2} \mathrm{O}_{5}$. Ionic liquids were stored and sampled in a dry-helium glove box prior to DSC measurements. The DSC was under a dry-nitrogen hood with continuous flushing. Samples were cooled with liquid nitrogen to $-120{ }^{\circ} \mathrm{C}$ and kept at this temperature for $30 \mathrm{~min}$, heated well above the melting point and cooled again. Scanning rate was $10{ }^{\circ} \mathrm{C} / \mathrm{min}$. Meltingpoints and glass-transition temperatures were taken from the second heating curve. The precision of our measurements is $\pm 1{ }^{\circ} \mathrm{C}$.

Thermal stability of ILs was investigated by thermo-gravimetric analysis (TGA) using a Perkin Elmer TGA 7. Dried ionic-liquid samples were stored and sampled in a dry-helium glove box. The TGA sample holder was under dry-nitrogen flow. Similar sample sizes were used at the same heating rate, $10{ }^{\circ} \mathrm{C} / \mathrm{min}$. Precision of our decomposition temperature measurements is $\pm 5^{\circ} \mathrm{C}$.

Table 1. Glass-transition temperatures $t_{g}$, melting points $t_{\mathrm{m}}$, and decomposition temperatures $t_{d}$ for selected pyrrolidinium and piperidinium ionic liquids. All temperatures are in Celsius.

\begin{tabular}{|c|c|c|c|}
\hline & $t_{\mathrm{g}}$ & $t_{\mathrm{m}}$ & $t_{\mathrm{d}}$ \\
\hline $\mathrm{CMPPyrro}^{+}\left[\mathrm{Tf}_{2} \mathrm{~N}\right]^{-}$ & - & $7,12^{\mathrm{a}}$ & 343 \\
\hline${ }_{[\mathrm{MBPyrro}]^{+}\left[\mathrm{Tf}_{2} \mathrm{~N}\right]^{-}}$ & -86 & -18 & 340 \\
\hline$\left[\mathrm{MOPyrro}^{+}\left[\mathrm{Tf}_{2} \mathrm{~N}\right]^{-}\right.$ & -81 & - & 325 \\
\hline$[\mathrm{MBPyrro}]^{+}\left[\mathrm{BF}_{4}\right]^{-}$ & - & 78 & $310\left(225-300^{\circ} \mathrm{C} 4 \mathrm{wt}-\%\right.$ loss $)$ \\
\hline$\left[\mathrm{MBPyrro}^{+}\left[\mathrm{AsF}_{6}\right]^{-}\right.$ & - & 66 & 325 \\
\hline$\left[\right.$ MPPip $^{+}\left[\mathrm{Tf}_{2} \mathrm{~N}\right]^{-}$ & - & $9^{b}$ & 341 \\
\hline 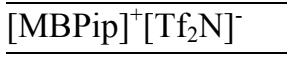 & -73 & - & 320 \\
\hline $\mathrm{MMOPip}^{+}\left[\mathrm{Tf}_{2} \mathrm{~N}\right]^{-}$ & -76 & - & 315 \\
\hline$\left[\mathrm{MOPip}^{+}\left[\mathrm{BF}_{4}\right]^{-}\right.$ & - & 92 & $325\left(215-325^{\circ} \mathrm{C} 4 \mathrm{wt}-\%\right.$ loss $)$ \\
\hline 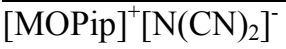 & -70 & - & 200 \\
\hline 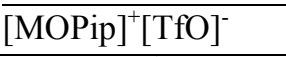 & - & 47 & 300 \\
\hline
\end{tabular}

${ }^{a}$ ref.. $34 ;{ }^{b}$ ref. 35.

Figure 2 shows thermal decomposition profiles for several mixtures that simulate battery electrolytes. The polymer was poly(2,2,6,6)-tetramethylpiperidinyloxy) methacrylate (PTMA). Figure 2 shows a thermal decomposition temperature near $200^{\circ} \mathrm{C}$, similar to those of other commonly used polymer electrolytes like polyvilynidene fluoride (PVDF) and polymethyl methacrylate (PMMA). The thermal stability is compared with those of ordinary volative and flammable battery electrolytes ethylene carbonate (EC) and ethylmethyl carbonate $(\mathrm{EMC})$ mixtures with and without $\mathrm{LiPF}_{6}$. The measurements were carried 
out in an open platinum pan under dry-nitrogen flow. The temperature rate was $10{ }^{\circ} \mathrm{C} /$ $\min$.

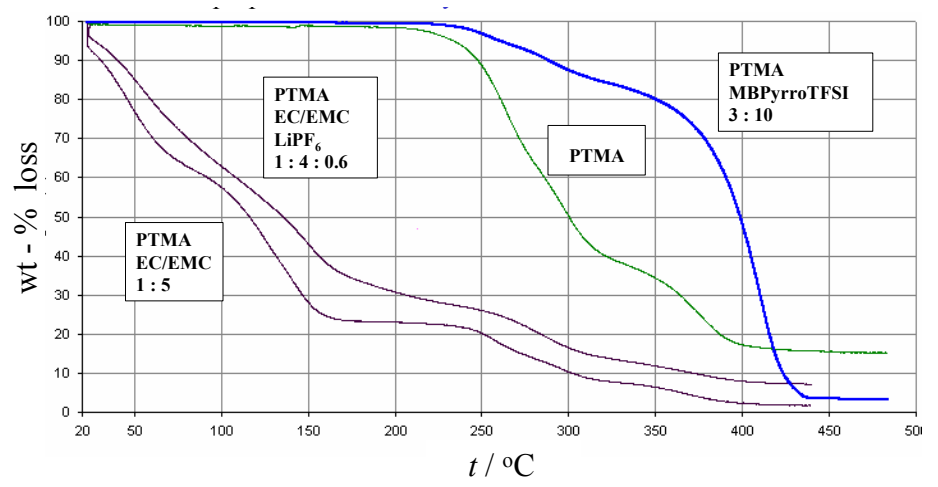

Figure 2. TGA curves for PTMA-[MBPyrro][Tf $2 \mathrm{~N}]$, pure PTMA, and PTMA-EC/EMC mixtures with and without $\mathrm{LiPF}_{6}$. The compositions are in mass ratio.

Figure 3 shows a thermal run for a PTMA-Carbon-[MBPyrro][Tf $\left.\mathrm{T}_{2} \mathrm{~N}\right]$ mixture with and without $\operatorname{LiTf}_{2} \mathrm{~N}$. DSC was used for measurements that simulate a battery electrolyte mixture. We used closed aluminium pans that can hold up to 2 bar pressure. The temperature rate was $10{ }^{\circ} \mathrm{C} / \mathrm{min}$. Similar measurements with volatile and flammable battery electrolytes ethylene carbonate (EC) and ethyl-methyl carbonate (EMC) show lower stability; the DSC pan breaks at $150^{\circ} \mathrm{C}$. Figure 3 shows that higher thermal stabilities are obtained when non-volatile ILs are used.

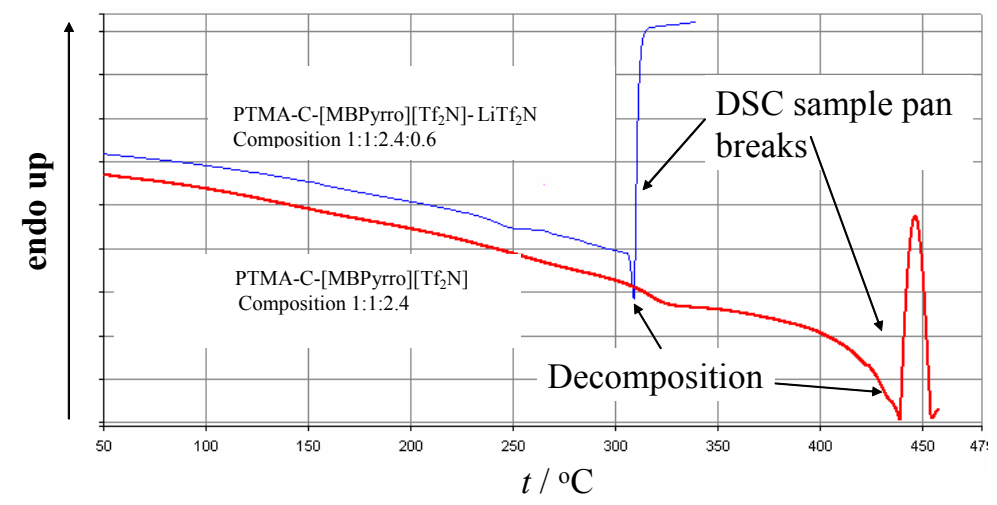

Figure 3. DSC measurements for a simulated battery electrolyte mixture. The measurements were carried out in a closed aluminium pan that can hold up to 2 bar pressure. Compositions are in mass ratio. 


\section{Conductivity and viscosity}

Conductivities of neat piperidinium and pyrrolidinium ILs were measured. Samples were dried and stored in a dry-helium glove box prior to measurement. For results above $30{ }^{\circ} \mathrm{C}$, the samples were kept at constant temperature for at least 1 hour prior to measurement. Subambient-temperature samples were kept for at least 15 hours at constant temperature prior to measurement. Conductivities were measured by the $\mathrm{AC}$ impedance method using a (steel | ionic liquid | steel), Swagelok-type cell. We used a Solatron, Schlumberger 1254 four-channel frequency response analyzer. The frequency sweep was from 66000 to $1 \mathrm{~Hz}$ at $5 \mathrm{mV}$ AC amplitude. With known cell thickness L, cell area A and bulk resistance $\Omega$, the conductivity $\kappa$ is obtained from

$\kappa\left(\mathrm{Scm}^{-1}\right)=\mathrm{L}(\mathrm{cm}) \cdot\left[\mathrm{A}\left(\mathrm{cm}^{2}\right)\right]^{-1} \cdot[\Omega(\mathrm{ohm})]^{-1}$

Figure 4 shows conductivities of piperidinium and pyrrolidinium $\left[\mathrm{Tf}_{2} \mathrm{~N}\right]^{-}$ionic liquids from -20 to $100{ }^{\circ} \mathrm{C}$.

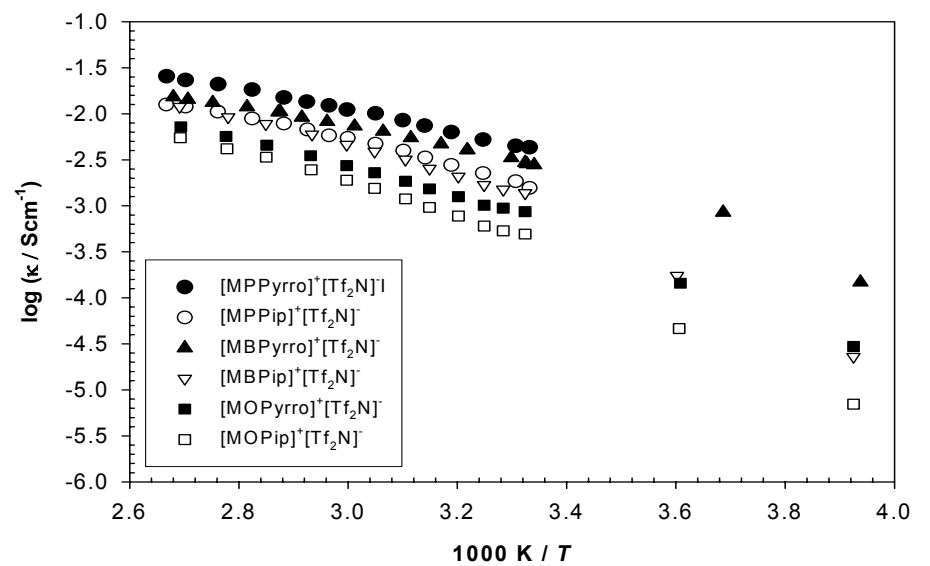

Figure 4. Conductivities of some ionic liquids containing pyrrolidinium or piperidinium cations and $\left[\mathrm{Tf}_{2} \mathrm{~N}\right]^{-}$anions.

Viscosities between 0 and $70{ }^{\circ} \mathrm{C}$ were measured using an ARES Rheometric Scientific viscosimeter. Samples were dried and stored in a dry-helium glove box prior to measurement. Sampling and measurements were carried out under dry nitrogen. Before each measurement, the sample was kept 30 min inside the rheometer at $100^{\circ} \mathrm{C}$ under drynitrogen flow. Figure 5 shows viscosities of piperidinium and pyrrolidinium $\left[\mathrm{Tf}_{2} \mathrm{~N}\right]^{-}$ionic liquids as a function of temperature. 


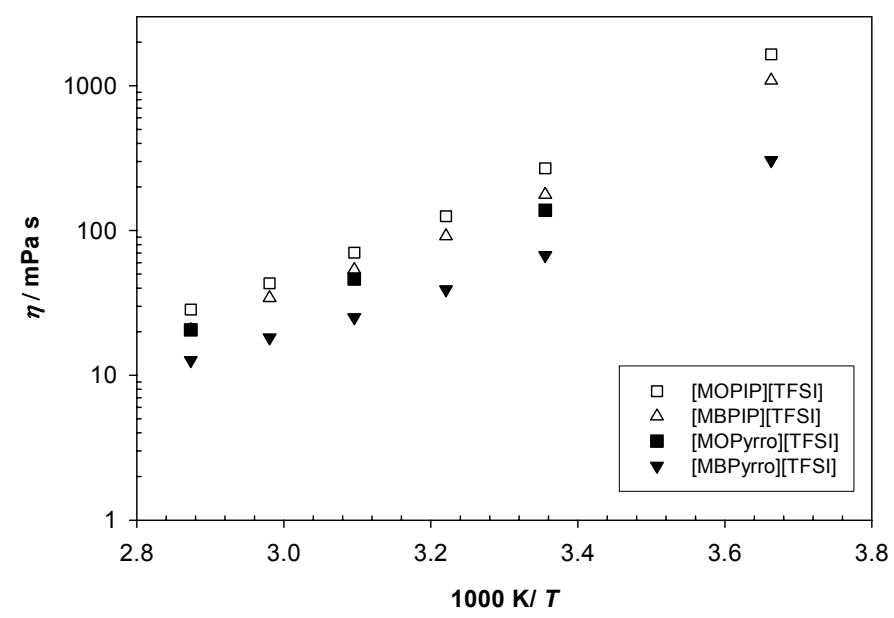

Figure 5. Viscosities of some ionic liquids containing pyrrolidinium or piperidinium cations and $\left[\mathrm{Tf}_{2} \mathrm{~N}\right]^{-}$anions.

\section{Mutual solubilities of water and hydrophobic ionic liquids}

The solubility of an ionic liquid in water can be modified by molecular design. Both cation and anion contribute to hydrophobic behavior. Lewis-acid-type anions increase while hydrophobic anions like $\left[\mathrm{Tf}_{2} \mathrm{~N}\right]^{-}$decrease solubility. Solubility falls as the alkyl chain length on the cation rises.

The solubility in water of an ionic liquid containing pyrrolidinium or piperidinium cations was determined visually. Various amounts of ionic liquid were added to water, mixed for 24 hours and centrifuged. The solubility limit was determined by observing the disappearance of the ionic liquid phase at constant temperature. Table 2 shows solubilities in water for selected pyrrolidinium and piperidinium $\left[\mathrm{Tf}_{2} \mathrm{~N}\right]^{-}$ionic liquids in water at $25^{\circ} \mathrm{C}$. The water content of an ionic liquid was measured by the Karl-Fischer method using a Mettler-Toledo coulometer. Water contents were measured when the ionic liquid was exposed to humid air or to liquid water. The water content of a humid-air-saturated ionic liquid was measured by first exposing an ionic liquid to humid air for a week. Then, a sample was taken and the water content of the ionic liquid was measured at least three times. Air humidity was also recorded.

Water content of a water-saturated ionic liquid was measured by mixing liquid water and ionic liquid for 24 hours. After that, the two-phase system was centrifuged and left in 
contact for another 24 hours to reach equilibrium. Then, a sample of ionic liquid was taken and the water content of the ionic liquid was measured. All measurements were repeated at least three times. The water contents of ionic liquids are precise to $\pm 7 \%$. Results are shown in Table 2.

Table 2. Solubilities of selected ionic liquids in water. Water solubilities in ionic liquids are tabulated at relative humidity $40 \%$ and in liquid-water saturated systems. Mass fraction $w$ is in ppm.

\begin{tabular}{lccc} 
& w (sol. in water) & w(humid-air sat) & w(water sat) \\
\hline$[\mathrm{MPPyrro}]^{+}\left[\mathrm{Tf}_{2} \mathrm{~N}\right]^{-}$ & $8200-9900$ & 5190 & 13200 \\
\hline$[\mathrm{MBPyrro}]^{+}\left[\mathrm{Tf}_{2} \mathrm{~N}\right]^{-}$ & $5900-6100$ & 3450 & 11700 \\
\hline$\left[\mathrm{MOPyrro}^{+}\left[\mathrm{Tf}_{2} \mathrm{~N}\right]^{-}\right.$ & $500-540$ & 2930 & 8370 \\
\hline$\left[\mathrm{MPPip}^{+}\left[\mathrm{Tf}_{2} \mathrm{~N}\right]^{-}\right.$ & $6900-8000$ & 4220 & 11700 \\
\hline$[\mathrm{MBPip}]^{+}\left[\mathrm{Tf}_{2} \mathrm{~N}\right]^{-}$ & $3600-4400$ & 3610 & 10050 \\
\hline$[\mathrm{MOPip}]^{+}\left[\mathrm{Tf}_{2} \mathrm{~N}\right]^{-}$ & $<200$ & 2260 & 6590 \\
\hline$[\mathrm{MOPip}]^{+}\left[\mathrm{N}(\mathrm{CN})_{2}\right]^{-}$ & $\mathrm{Nd}$ & 49330 & $>50000$ \\
\hline
\end{tabular}

nd: not determined

\section{Cytotoxicity}

The literature refers to ionic liquids as new, green, and non-toxic solvents. However, there are few published data on toxicity or studies on the possible environmental impact of ionic liquids. We estimated the cellular toxicity or cytotoxicity of a variety of piperidinium and pyrrolidinium $[\mathrm{Br}]^{-}$and $\left[\mathrm{Tf}_{2} \mathrm{~N}\right]^{-}$ILs. An accepted metric of cytotoxicity is $\mathrm{IC}_{50}$, which corresponds to the concentration of the agent at which $50 \%$ of the cells are dead (or alive). ${ }^{36}$ The lower the $\mathrm{IC}_{50}$, the higher the toxicity.

Cytotoxicity was assessed using human breast cancer cell line, MCF7. The MCF7 cells, originally purchased from ATCC, were cultured in Dulbecco's Modified Eagles' Medium (DMEM) supplemented with $5 \%$ fetal bovine serum (FBS) and $1 \%$ penicillin/streptomycin. The cells were plated out in 96-well plates at a density of 10,000 cells/well contained in $100 \mu \mathrm{l}$ of media. After one day of growth, the cells were exposed to different concentrations of ionic liquid. After $24 \mathrm{~h}$ exposure, the cells were washed twice with $200 \mu \mathrm{l}$ of phosphate buffered saline (PBS), and $100 \mu \mathrm{l}$ of media was added to each well, and the plates were returned to the incubator. After 2 days of growth, the cells were 
assessed for toxicity by 1-(4,5-dimethylthiazol-2-yl)-3,5-diphenylformazan (MTT) assay. $25 \mu \mathrm{l}$ of $2.5 \mathrm{mg} / \mathrm{ml}$ MTT in (PBS) was added to each well, and was incubated for $4 \mathrm{~h}$ at 37 ${ }^{\circ} \mathrm{C}$. The yellow MTT is reduced to purple formazan crystals because of mitochondrial reductase and is hence proportional to the number of viable cells. The media was aspirated out and the crystals were solubilized in dimethyl sulfoxide. The absorbance was quantified at $570 \mathrm{~nm}$ using a spectrophotometer, and was used as a measure of live-cell population. The experiments were performed in 6-8 replicates at each dose and typically 12 doses were tested for each ionic liquid. The dose response curves were fitted to a Hill equation using a non-linear least squares method and the $\mathrm{IC}_{50}$ were evaluated.

We measured the cytotoxicity of selected piperidinium and pyrrolidinium compounds using MCF7 cells. Figure $6 a$ shows the toxicity profiles of $[\mathrm{MPPip}]^{+}[\mathrm{Br}]^{-}$and $[\mathrm{MOPip}]^{+}[\mathrm{Br}]^{-}$ ionic liquids on MCF7 cells. Table 3 shows toxicities of ionic liquids containing pyrrolidinium or piperidinium cations with $[\mathrm{Br}]^{-}$.

Table 3. Toxicities of pyrrolidinium and piperidinium-type ionic liquids, expressed in terms of $\mathrm{IC}_{50}$. Toxicity of sodium bromide is shown for comparison. The most toxic liquids are those with the lowest $\mathrm{IC}_{50}$.

\begin{tabular}{llc} 
& $\mathrm{IC}_{50}(\mathrm{mM})$ & $\log (\mathrm{IC} 50) \pm \mathrm{SE}$ \\
\hline $\mathrm{NaBr}$ & 94.6 & $1.98 \pm 0.034$ \\
\hline$[\mathrm{MPPyrro}]^{+}[\mathrm{Br}]^{-}$ & 43.40 & $1.64 \pm 0.02$ \\
\hline$[\mathrm{MBPyrro}]^{+}[\mathrm{Br}]^{-}$ & 17.80 & $1.25 \pm 0.05$ \\
\hline$[\mathrm{MOPyrro}]^{+}[\mathrm{Br}]^{-}$ & 0.080 & $-1.11 \pm 0.12$ \\
\hline$[\mathrm{MPPip}]^{+}[\mathrm{Br}]^{-}$ & 24.70 & $1.39 \pm 0.18$ \\
\hline$[\mathrm{MBPip}]^{+}[\mathrm{Br}]^{-}$ & 14.00 & $1.15 \pm 0.04$ \\
\hline$[\text { MOPip] }]^{+}[\mathrm{Br}]^{-}$ & 0.54 & $-0.27 \pm 0.03$ \\
\hline
\end{tabular}

A plot of $\mathrm{IC}_{50}$ against the number of carbons of the alkyl chain appended to the cation shows a linear relationship as shown in Figure 6b. We obtained a correlation between $\mathrm{IC}_{50}$ and the number of carbon atoms in the alkyl chain as, for alkyl-methyl-pyrrolidinium bromide compounds, $\log _{10}\left(\mathrm{IC}_{50}\right)=-0.5606 \cdot \mathrm{n}+3.3958$; and for alkyl-methyl-piperidinium bromide compounds, $\log _{10}\left(\mathrm{IC}_{50}\right)=-0.3383 \cdot n+2.4489$. The correlation coefficient $\mathrm{r}^{2}$ was 0.9973 for the piperidinium ILs, and 0.9965 for the pyrrolidinium ILs. 
(a)

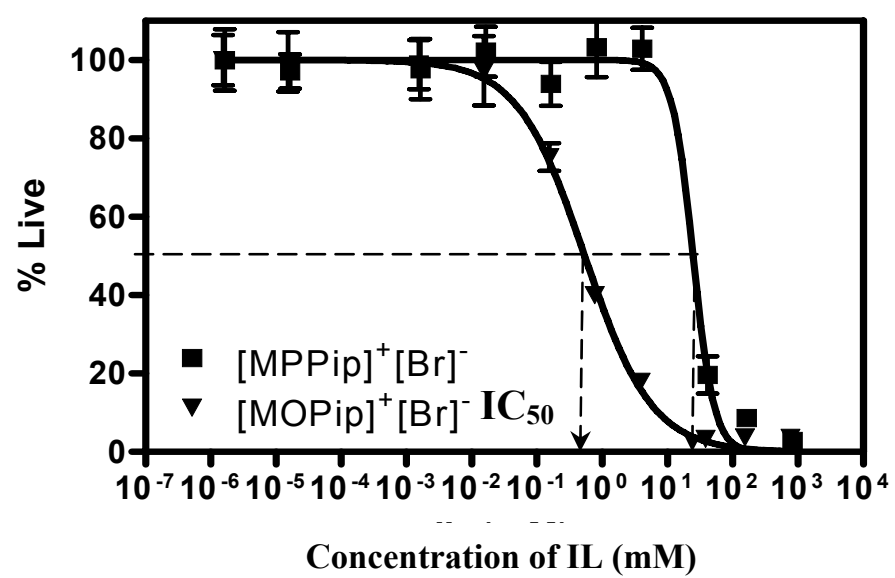

(b)

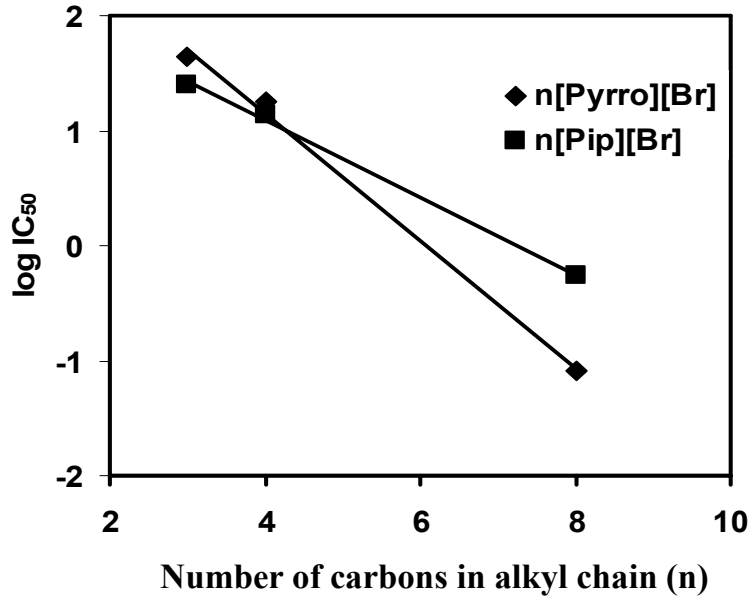

Figure 6. (a) Representative toxicity profiles for two ionic liquids. (b) Effect of alkyl chain length on toxicity of ionic liquids to mammalian cells. The points are measured results for propyl, butyl, and octyl-type ILs shown in Tables 4 and 5.

Table 4. Experimental and calculated toxicities for n-methyl-pyrrolidinium bromide compounds. Calculated results from $\log _{10}\left(\mathrm{IC}_{50}\right)=-0.5606 \cdot \mathrm{n}+3.3958$

\begin{tabular}{|c|c|c|c|}
\hline n & {$[\text { alkyl-methyl-Pyrro] }]^{+}[\mathrm{Br}]-$} & $\mathrm{IC}_{50}$ Calc. / (mM) & $\mathrm{IC}_{50} \operatorname{Exp} . /(\mathrm{mM})$ \\
\hline 2 & {$[\text { Ethyl-methyl-Pyrro }]^{+}[\mathrm{Br}]^{-}$} & 188 & \\
\hline 3 & {$[\text { Propyl-methyl-Pyrro }]^{+}[\mathrm{Br}]^{-}$} & 51.8 & 43.4 \\
\hline 4 & {$\left[\right.$ Butyl-methyl-Pyrro] ${ }^{+}[\mathrm{Br}]-$} & 14.3 & 17.8 \\
\hline 5 & {$[\text { Pentyl-methyl-Pyrro }]^{+}[\mathrm{Br}]^{-}$} & 3.9 & \\
\hline 6 & {$[\text { Hexyl-methyl-Pyrro }]^{+}[\mathrm{Br}]^{-}$} & 1.1 & \\
\hline 7 & {$[\text { Heptyl-methyl-Pyrro }]^{+}[\mathrm{Br}]^{-}$} & 0.3 & \\
\hline 8 & {$[\text { Ooctyl-methyl-Pyrro }]^{+}[\mathrm{Br}]^{-}$} & 0.08 & 0.078 \\
\hline
\end{tabular}

Table 5. Experimental and calculated toxicities for n-methyl-pyrrolidinium bromide salts. Predicted values were calculated from: $\log _{10}\left(\mathrm{IC}_{50}\right)=-0.3383 \cdot \mathrm{n}+2.4489$

\begin{tabular}{|c|c|c|c|}
\hline & 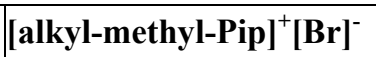 & IC $_{50}$ Calc. / (mM) & $\mathrm{IC}_{50} \operatorname{Exp} /(\mathrm{mM})$ \\
\hline 2 & {$[\text { Ethyl-methyl-Pip] }]^{+}[\mathrm{Br}]-$} & 59.2 & \\
\hline 3 & {$[\text { Propyl-methyl-Pip }]^{+}[\mathrm{Br}]-$} & 27.2 & 24.7 \\
\hline 4 & [Butyl-methyl-Pip] $]^{+}[\mathrm{Br}]-$ & 12.5 & 14.0 \\
\hline 5 & {$[\text { Pentyl-methyl-Pip }]^{+}[\mathrm{Br}]-$} & 5.7 & \\
\hline 6 & [Hexyl-methyl-Pip] $]^{+}[\mathrm{Br}]-$ & 2.7 & \\
\hline 7 & {$[\text { Heptyl-methyl-Pip }]^{+}[\mathrm{Br}]-$} & 1.2 & \\
\hline 8 & [Octyl-methyl-Pip] $]^{+}[\mathrm{Br}]-$ & 0.6 & 0.54 \\
\hline
\end{tabular}




\section{Discussion}

As expected, the length of the alkyl chain appended to the cation has a significant influence on the melting points of ionic liquids containing pyrrolidinium or piperidinium cations. $[\mathrm{MPPyrro}]^{+}\left[\mathrm{Tf}_{2} \mathrm{~N}\right]^{-}$and $[\mathrm{MPPip}]^{+}\left[\mathrm{Tf}_{2} \mathrm{~N}\right]^{-}$have higher melting points than $[\mathrm{MBPyrro}]^{+}\left[\mathrm{Tf}_{2} \mathrm{~N}\right]^{-}$or $[\mathrm{MBPip}]^{+}\left[\mathrm{Tf}_{2} \mathrm{~N}\right]^{-} \cdot \quad[\mathrm{MBPip}]^{+}\left[\mathrm{Tf}_{2} \mathrm{~N}\right]^{-}, \quad[\mathrm{MOPyrro}]^{+}\left[\mathrm{Tf}_{2} \mathrm{~N}\right]^{-}$and $[\mathrm{MOPip}]^{+}\left[\mathrm{Tf}_{2} \mathrm{~N}\right]^{-}$show no melting points, only glass-transition temperatures at $-73,-81$ and $-76{ }^{\circ} \mathrm{C}$, respectively. Ionic liquids increase thermal stability and safety in applications because, at normal temperatures, they are non-volatile and non-flammable. Thermal stabilities are all above $300{ }^{\circ} \mathrm{C}$, except for $[\mathrm{MOPip}]^{+}\left[\mathrm{N}(\mathrm{CN})_{2}\right]^{-}$that starts to decompose near $200{ }^{\circ} \mathrm{C}$. Similar results were observed for other ILs containing dicyanamide anion. ${ }^{15,16}$ Ionic liquids increase thermal stability of electrolyte mixtures used in batteries.

The conductivity of an IL depends on the alkyl-chain length. [MPPyrro $]^{+}\left[\mathrm{Tf}_{2} \mathrm{~N}\right]^{-}$shows highest conductivities. Conductivities and viscosities are nearly inversely proportional. ILs containing pyrrolidinium show higher conductivities than their piperidinium homologues. [MPPyrro $]^{+}\left[\mathrm{Tf}_{2} \mathrm{~N}\right]^{-}$shows the lowest viscosity and the highest conductivity. It also appears that piperidinium ILs systematically show higher viscosities and lower conductivities than their pyrrolidinium homologues. Highest viscosity and lowest conductivity were obtained for $[\mathrm{MOPip}]^{+}\left[\mathrm{Tf}_{2} \mathrm{~N}\right]^{-}$.

There is little influence of alkyl-chain length or nature of the cation ring on the water contents of ionic liquids containing pyrrolidinium or piperidinium cations.

For humid-air-saturated $[\mathrm{MPPyrro}]^{+}\left[\mathrm{Tf}_{2} \mathrm{~N}\right]^{-},[\mathrm{MBPyrro}]^{+}\left[\mathrm{Tf}_{2} \mathrm{~N}\right]^{-}$and $[\mathrm{MOPyrro}]^{+}\left[\mathrm{Tf}_{2} \mathrm{~N}\right]^{-}$, water contents are close, between 5190 and 2930 ppm. For humid-air-saturated $[\mathrm{MPPip}]^{+}\left[\mathrm{Tf}_{2} \mathrm{~N}\right]^{-},[\mathrm{MBPip}]^{+}\left[\mathrm{Tf}_{2} \mathrm{~N}\right]^{-}$and $[\mathrm{MOPip}]^{+}\left[\mathrm{Tf}_{2} \mathrm{~N}\right]^{-}$, water contents are between 4220 and $2660 \mathrm{ppm}$. Ionic liquids containing piperidinium cations appear to have lower water contents than their pyrrolidinium homologues. A similar trend is observed for water contents of water-saturated ionic liquids.

The influence of a cation on the solubility of an ionic liquid in water is much more pronounced. Increase of the alkyl chain, from butyl to octyl, leads to a decrease by one order of magnitude in the solubility in water. [MBPyrro $]^{+}\left[\mathrm{Tf}_{2} \mathrm{~N}\right]^{-}$and $[\mathrm{MOPyrro}]^{+}\left[\mathrm{Tf}_{2} \mathrm{~N}\right]^{-}$ have solubilities in water of $6000 \mathrm{ppm}$ and around $600 \mathrm{ppm}$, respectively. [MBPip] $]^{+}\left[\mathrm{Tf}_{2} \mathrm{~N}^{-}\right.$ and $[\mathrm{MOPip}]^{+}\left[\mathrm{Tf}_{2} \mathrm{~N}\right]^{-}$exhibit solubilities in water of approximately $4000 \mathrm{ppm}$ and below 
$200 \mathrm{ppm}$, respectively. ILs containing piperidinium cations show lower solubilities in water than their pyrrolidinium homologues.

Solubilities in water for hydrophobic ionic liquids containing pyridinium and imidazolium cations have been reported previously; they are of the same order of magnitude as those shown here. [MOPip $]^{+}\left[\mathrm{Tf}_{2} \mathrm{~N}\right]^{-}$, however appears to have the lowest solubility in water reported for an ionic liquid containing $\left[\mathrm{Tf}_{2} \mathrm{~N}\right]^{-}$anion. $[\mathrm{MOPip}]^{+}\left[\mathrm{N}(\mathrm{CN})_{2}\right]^{-}$is sufficiently hydrophobic to form two liquid phases when contacted with a similar amount of water. Solubility in water is, however, relatively high. It has the largest water content when saturated with humid air or liquid water.

There has been sufficient interest in the recent past on toxic effects of ionic liquids on microorganisms ${ }^{24,27,28}$ and on mammalian cells. ${ }^{22,25}$ We estimated the cytotoxicities of pyrridinium and piperidinium ionic liquids and they fall in the same range as imidazolium ionic liquids. ${ }^{25,27}$ In addition, we observed that the toxicities of pyrridinium and piperidinium ionic liquids increase with an increase in the alkyl chain length, similar to that of imidazolium ionic liquids (Fig. 6b).

Toxicity for $[\mathrm{MPPyrro}]^{+}[\mathrm{Br}]^{-}$is the lowest measured here but it is higher than that for $\mathrm{NaBr}$. [MPPyrro $]^{+}[\mathrm{Br}]^{-}$shows lower toxicity than [MPPip $]^{+}[\mathrm{Br}]^{-}$, but $[\mathrm{MOPyrro}]^{+}[\mathrm{Br}]^{-}$ shows a higher toxicity than $[\mathrm{MOPip}]^{+}[\mathrm{Br}]^{-}$. The logarithm of $\mathrm{IC}_{50}$ values is a linear function of the number of carbons of the cation's alkyl chain. Table 4 and 5 show toxicity values calculated for ionic liquids with various alkyl chain lengths. It appears that the calculated toxicity for [MEPyrro $]^{+}[\mathrm{Br}]^{-}$is twice as low as that for $\mathrm{NaBr}$. There are hardly any human cancer-cell toxicity studies in the literature. Our separate studies with the same experimental set-up showed that piperidinium and pyrrolidinium are circa 10 times less toxic than their pyridinium homologues. ${ }^{26}$ Also we found that $\left[\mathrm{Tf}_{2} \mathrm{~N}\right]^{-}$anion appears to increase toxicity compared to $[\mathrm{Br}]^{-}$. Except with $[\mathrm{MOPyrro}]^{+}$cation, replacing $[\mathrm{Br}]^{-}$ anion with $\left[\mathrm{Tf}_{2} \mathrm{~N}\right]^{-}$yield toxicities increased by one order of magnitude. For $[\mathrm{MOPyrro}]^{+}[\mathrm{Br}]^{-}$and $[\mathrm{MOPyrro}]^{+}\left[\mathrm{Tf}_{2} \mathrm{~N}\right]^{-}$, toxicities are similar.

\section{Acknowledgements}

The authors are grateful to the Office for Basic Sciences, U. S. Department of Energy, NIH, and to TEKES for financial support; to Prof. Douglas Clark from the University of 
California, Berkeley for allowing us to use his laboratory for performing cytotoxicity studies; and to Terhi Rantala from Helsinki University of Technology for assistance.

\section{References}

1. P. Bonhote, A.-P. Dias, N. Papageorgiou, K. Kalyanasundaram, M. Graetzel, Inorg. Chem. 35 (1996) 1168-1178.

2. J.K. Holbrey, K.R. Seddon, J. Chem. Soc., Dalton Trans. (1999) 2133-2140.

3. J.G. Huddleston, A.E. Visser, W.M. Reichert, H.D. Willauer, G.A. Broker, R.D. Rogers, Green Chem. 3(4) (2001) 156-164.

4. B.D. Fitchett, T.N. Knepp, J.C. Conboy, J. Electrochem. Soc. 151(7) (2004) 219-225.

5. H. Tokuda, K. Hayamizu, K. Ishii, Md. A. B. H. Susan, M. Watanabe, J. Phys. Chem. B 108 (2004) 16593-16600.

6. J. Van der Broeke, M. Stam, M. Lutz, H. Koojjman, A.L. Spek, B.-J. Deelman, G. van Koten, Eur. J. Inorg. Chem. 15 (2003) 2798-2811.

7. J. Finden, G. Beck, A. Lantz, R. Walsh, M.J. Zaworotko, R.D. Singer, J. Chem. Crystal. 33(4) (2003) 287-295.

8. J. M. Crosthwaite, M. J. Muldoon, J. K. Dixon, J. L. Anderson, J.F. Brennecke, J. Chem. Therm. 37 (2005) 559-568.

9. J.H. Davis Jr., Chem. Lett. 33(9) (2004) 1072-1077.

10. H. Tokuda, K. Hayamizu, K. Ishii, A. B. H. Susan, M. Watanabe, J. Phys. Chem. B 108 (2004) 16595-16600.

11. C. P. Fredlake, J. M. Crosthwaite, D. G. Hert, S. N. V. K. Aki, J.F. Brennecke, J. Chem. Eng. Data 49 (2004) 954-964.

12. D. R.MacFarlane, J. Golding, S. Forsyth, M. Forsyth, G.B. Deacon, Chem. Comm. (2001) 1430-1431.

13. K.R. Harris, M. Kanakubo, L.A. Woolf, J. Chem. Eng. Data 51 (2006) 1161-1167.

14. H. Sakaebe and H. Matsumoto, Electrochem. Comm. 5 (2003) 594.

15. N. Papaiconomou, N. Yakelis, J. Salminen, R. Bergman, J.M. Prausnitz, J. Chem. Eng. Data 51 (2006) 1389-1393.

16. N. Papaiconomou, J. Salminen, J.-M. Lee, J. M. Prausnitz, J. Chem. Eng. Data 52 (2007) 833-840. 
17. J. Ranke, A. Muller, U. Bottin-Weber, F. Stock, S. Stolte, J. Arning, R. Stormann, and B. Jastroff, Ecotox. Environ. Saf., Epub 9.9.2006.

18. D. Zhao, Y. Liao, Z. Zhang, CLEAN - Soil Air Water, 35(1) (2007) 42-48.

19. J. Ranke, M. Cox, A. Mueller, C. Schmidt, D. Beyersmann, Toxicol. Environ. Chem., 88(2) (2006) 273-285.

20. S. Stefan, A. Juergen, U. Bottin-Weber, M. Matzke, F. Stock, K. Thiele, M. Uerdingen, U. Welz-Biermann, B. Jastorff, J. Ranke, Green Chem., 8(7) (2006) 621-629. 21. B. Jastorff et al., Green Chem., 7 (2005) 362-372.

22. P. Stepnowski, A.C. Skladanowski, A. Ludwiczak, E. Laczynska, Human \& Experimen. Toxicol. 23(11) (2004) 513-517.

23. A. Latala, P. Stepnowski, M. Nedzi, W. Mrozik, Aquatic Toxicol. 73(1) (2005) 91-98.

24. K.M. Docherty, C.F. Kulpa, Green Chem. 7(4) (2005) 185-189.

25. S. Stolte, J. Arning, U. Bottin-Weber, A. Müller, W.-R. Pitner, U. Welz-Biermann, B. Jastorff, J. Ranke, Green Chem., Epub 9.3.2007.

26. A.R. Kumar, J. Salminen, N. Papaiconomou, D. Clark, J.M. Prausnitz, BATIL Meeting: Biodegrability and Toxicity of Ionic Liquids, Berlin, Germany, 6.-8.5.2007, OP. 27. Ranke, J., K. Molter, F. Stock, U. Bottin-Weber, J. Poczobutt, J. Hoffmann, B. Ondruschka, J. Filser and B. Jastroff, Ecotox. Environ. Safety, 58 (2004) 396-404.

28. Couling, D.J., R.J. Bernot, K.M. Docherty, J.K. Dixon and E.J. Maginn, Green Chem., 8 (2006) 82-90.

29. H. Luo, S. Dai, P.V. Bonnesen, Anal. Chem. 76(10) (2004) 2773-2779.

30. S.V. Dzyuba, R.A. Bartsch, Tetrahedron Lett. 43(26) (2002) 4657-4659.

31. A.E. Visser, R.P. Swatloski, W.M. Reichert, R. Mayton, S. Sheff, A. Wierzbicki, J.H. Davis Jr., R.D. Rogers, Environ. Sci. Tech. 36 (2002) 2523-2529.

32. S.T.M. Vidal, M.J.N Correia, M.M. Marques, M.R. Ismael, M.T.A. Reis, Sep. Sci. Tech. 39(9) (2004) 2155-2169.

33. Visser, A. E.; Swatloski, R. P.; Griffin, S. T.; Hartman, D. H.; Rogers, R. D., Sep. Sci. Tech. 36(5-6) (2001) 785-804.

34. D. MacFarlane, P. Meakin, J. Sun, N. Amini, M. Forsyth, J. Phys. Chem. B, 103 (1999) 4164-4170.

35. H. Sakaebe, H. Matsumoto, Electrochem. Comm., 5 (2003) 594-598. 
36. R. D. Blumenthal and D. M. Goldenberg, Mol. Biotechnol. 35 (2007) 185-197. 